European Journal of Accounting, Auditing and Finance Research

Vol.8, No.2, pp.38-58, February 2020

Published by ECRTD-UK

Print ISSN: 2053-4086(Print), Online ISSN: 2053-4094(Online)

\title{
CREDIT RISK AND FINANCIAL PERFORMANCE: AN EMPIRICAL STUDY OF DEPOSIT MONEY BANKS IN NIGERIA
}

\author{
Adegbie F.Folajimi ${ }^{1}$ Ph.D, Fca \\ Otitolaiye Emmanuel Dare ${ }^{2}$ MSc, FCA. \\ 1adegbiefa@babcock.edu.ng, ${ }^{2}$ eotitolaiye@gmail.com \\ ${ }^{1-2}$ Department of Accounting \\ Babcock University, Ilishan-Remo Ogun State
}

\begin{abstract}
Money deposit banks' ability to mitigate credit risks has been a contemporary and controversial debate in literature, in contributing and extending the frontiers, this study examined the effect of credit risk on financial performance of money deposit banks in Nigeria. The study adopted an expo facto research design, descriptive and using inferential statistics to analyse the data. The population consisted of all the 19 money deposits banks (MDB) listed on the Nigeria stock exchange as at $31^{\text {st }}$ December, 2018. A sample of 13 MDB were chosen on purpose, based mainly on availability of complete data within the study period under consideration. The study covered 169 firm-year observations for the period of 2006-2018. The study extracted secondary data from the financial statements of the banks explored for the study. The study identified three variables of financial performance (dependent variable) surrogated with return on capital employed (ROCE), the independent variable of credit risk proxied with non-performing loans, capital adequacy ratio, loan loss provisions loan to deposit ratio and the control variables of bank Size. The study found that credit management had a positive significant effect on financial performance of the $M D B .\left(A d R^{2}=0.028, F(4,4170)=2.26\right.$; $P$-value $\left.<0.05\right)$ When the control variable of bank size (BSZ), stronger effect was exhibited, the study found that credit risk with bank size had a stronger significant effect on financial performance of MDB in Nigeria $\left(\right.$ Ad. $R^{2}=0.4311, F_{(4,4170)}=321.95 ; p$-value $\left.<0.05\right)$. The study concluded that credit management influences the financial performance of Deposit Money Banks in Nigeria. The study recommended that management of the MBD should design and maintain a robust credit management strategy and framework as well as stringent credit policy that would decrease nonperforming loan and default level; and improve their performance level in Nigeria.
\end{abstract}

KEYWORDS: capital employed, credit risk, financial performance, money deposit banks, nonperforming loans, dividend.

\section{INTRODUCTION}

Financial performance of deposits money banks globally is the hub and the pillars of every nation's economic and financial system, hence, the stability and underlying economic performance of deposit money banks is vital and paramount to the macroeconomic development of a nation(Mehmood, Hunjra \& Chani, 2019). The stakeholders in the banking industry ranging from 
European Journal of Accounting, Auditing and Finance Research

Vol.8, No.2, pp.38-58, February 2020

Published by ECRTD-UK

Print ISSN: 2053-4086(Print), Online ISSN: 2053-4094(Online)

depositors, investors, shareholders and the policy makers have high agitation on the performance of the credit portfolio of deposit money banks because of the risks inherent in not getting adequate returns on the investment. The uncertainties capitulating investment risks in portfolio management and non-performing loans give management undesired apprehensions within the corridors of the stakeholders, as many banks now resort to unhealthy practices to mask recital and incompetence financial performance to the detriment of stakeholders (Hashem, Alduneibat, \& Altawalbeh, 2017). The lengthy history of corporate failure linked to banks poor banks performance and reporting failure are very worrisome as the cumulative impact of high profile cases had led to a steady loss of investments, credibility and confidence in the ability of banks to depositors funds and their credit risks (Walker, 2011).

Recently, the Central Bank of Nigeria CBN in a bid to manage and curb the looming credit management crisis recently issued a press release on January 31 and February 23, 2018 regulating dividend payment of financial institutions in accordance with their non-performing loans and capital adequacy ratios from paying dividend to his shareholders. DMBs with at least 3\% capital adequacy ratios above the minimum requirement, 'low' CRR and NPL ratio of more than 5\% but less than $10 \%$ shall pay not more than $75 \%$ of profit after tax. However, those that meet the minimum capital adequacy ratio but have 'above average' CRR or NPL ratio more than $5 \%$ but less than $10 \%$ can pay not more than $30 \%$ dividend payout ratio; while banks with 'High' composite risk rating (CRR) or above $10 \%$ non-performing loan (NPL) ratio are not be allowed to pay dividend.

Empirical evidence has shown that Nigerian financial industry is fraught with poor risk management practices such as absence of basic control measures, poor corporate governance, flagrant and excessive credit exposure, poor financial disclosure and transparency (Audu, 2014). In addition, huge non-performing loans, inter-bank indebtedness, contravention of supervisory and regulatory provision, weak internal control, insider abuse, massive exposure to few obligors, macroeconomic instability; and incessant bank distress and failure are also the realities of the banking system (Okorie \& Uwaleke, 2010). Palubinskas and Stough (1999) cited in (Kararach \& Otieno, 2016) disclosed that bank failures occur on account of poor credit management as a result of bad lending decisions, wrong credit appraisal, poor commitment to non-performing credits repayment and excessive credit lending drive. In congruence, IMF (1996) stated that out of its 181 member countries, about 133 had witnessed significant banking sector glitches and failures as a result of credit problems - bad real estate loans (Gup, 2011).

The quest to ascertain the implication of rising non-performing loans and other parameters of credit management on the financial performance of deposit money banks sparked the interest of the researcher in conducting this study. Considering that the House of Representatives in June 2017 was forced to foreclose AMCON from acquiring more toxic assets from deposit money banks. According to AMCON Chairman, Mr. Onyereri, the very high level of non-performing loans in the country is worse than the 2009 experience and far above the regulatory threshold. With debt obligation of AMCON standing at $\$ 4.6$ trillion (75\% of 2016 national budget) as at June 2017 and her foreclosure from absorbing toxic assets in the face of rising non-performing loan, the study seeks to investigate the effect of credit management on the return on capital employed of deposit 
European Journal of Accounting, Auditing and Finance Research

Vol.8, No.2, pp.38-58, February 2020

Published by ECRTD-UK

Print ISSN: 2053-4086(Print), Online ISSN: 2053-4094(Online)

money banks in Nigeria as well as the dividend per share of deposit money banks following the new directives issued by the CBN in 2018 (Kajola, Babatunji, Olabisi \& Babatolu, 2019). Deposit money banks (DMBs) create loans from deposits from customers and these loans are major income generating source for majority of the banks. However this intermediation function of DMBs is associated with enormous risks to both the banks and the deficit units (Okorie \& Uwaleke, 2010). Banks are now working so hard to attract the massive number of people who are not banking with them. This has led to an increase in banks surplus units and deficit units as well. With the aim of increasing revenue and gaining a large portion of the market share, many banks have given out loans and advances which could not be recovered leading to a massive growth in Non-Performing Loans (NPLs) in their accounts. This has become a worrisome situation for banks and other stakeholders.

Moreover, empirical evidences on credit management and financial performance of deposit money banks reveal conflicting results. A study by (Uwalomwa, Uwuigbe \& Oyewo, 2015) on Credit Management and Bank Performance of Listed Banks in Nigeria revealed that ratio of nonperforming loans and bad debt do not have a significant negative effect on the performance of banks in Nigeria. While secured and unsecured loan ratio and bank's performance was not significant. A study by (Abu, Sajeda, Mustafa \& Hasanul, 2015) on the effect of credit risk on the banking profitability in Bangladesh finds a robust negative and significant effect of nonperforming loan to gross loan, loan loss reserve to gross loan on all profitability indicators. The analysis also finds a negative and significant effect of capital adequacy ratio (CAR) on return on average equity. The implication is that the effect credit management has on a bank's financial performance cannot be undermined.

In further efforts to ensure financial stability and minimize banking sector distress, the guideline stipulated the minimum requirements for classifying and disclosing risk assets. It also made provision for bad and doubtful debts, interest accrual as well as off balance sheet engagement (Nwankwo, 1990). Credit facilities were classified into performing and non performing accounts. The criteria for further classification of non-performing loans were also provided. The banks were directed to neither accrue interest on non-performing loans nor recognize same as income. As a result, the hidden inefficiencies of the financial institutions were revealed and their 'paper profit' declarations truncated. (Adegbie, 2011). Other initiatives introduced to manage credit risk in Nigeria include CBN Act of 1991, Bank and Other Financial Institution Act (BOFIA) of 1991 and amendments, Credit Risk Management System (CRMS) of 1998 and 2005 banking reform reforms.

Despite the various schemes and reforms and guidelines, the banking industry continued to witness varying forms of distress and liquidity problems attributed to poor credit management. The most significant among the factors is the issue of non-performing loan. Non-performing loans, a consequence of poor credit management, has been repeatedly reported as the most remarkable factor of bank failures in Nigeria (Ugoani, 2015). Between 1994 and 2000, about thirty-three (33) banks collapsed due to high non-performing loans (Nwaze, 2006). The alarming level of nonperforming loans (NPLs) has constantly raised concerns of the monetary authorities (Nawaz, Munir, Siddiqui, Tahseen-ul-Ahad, Asif \& Ateeq, 2012). According to Ugoani (2015), the load of 
European Journal of Accounting, Auditing and Finance Research

Vol.8, No.2, pp.38-58, February 2020

Published by ECRTD-UK

Print ISSN: 2053-4086(Print), Online ISSN: 2053-4094(Online)

toxic assets of Nigerian banks rise progressively year after year. Illustratively, NPL rose from $\$ 21.27$ bn in 2002 to $\$ 260.19$ bn in 2003 and further to $\$ 350.82$ bn in 2004 (Ugoani, 2015). Between 2007 and 2008, the non-performing credit portfolio of First Bank of Nigeria Plc alone soared by thirty-four percent (34\%) from $\$ 2.021$ billion to $\$ 6.015$ billion (Ajekigbe, 2008).

However, the study carried out by Olabamiji and Michael (2018) on the effect influence of credit management practices on financial performance of Nigerian banks with specific reference to First bank Plc, showed that credit management practices have a significant positive influence on the financial performance of First bank. Thus, sound credit risk management and capital adequacy effected positively on the banks financial performance with the expectation of loan and advances which was found to have a negative effect on bank's profitability. In the study of (Taiwo, Ucheaga, Achugamonu, Adetiloye, Okoye \& Agwu; 2017) on the quantitative effect of credit risk management on the performance of Nigeria's Deposit Money Banks (DMBs) and Bank lending growth over the period of 17 years (1998-2014). The findings revealed that credit risk management has an insignificant effect on the growth of total loans and advances by Nigerian Deposit money banks. This implies that, there is still inconclusive and conflicting evidence on whether credit management affect the financial performance of banks in Nigeria, which motivates the reason for this study. The problems of the banks' nonperformance occasioned by nonperforming loan ratio and capital inadequacy ratio remain fundamental challenges of the money deposit banks in Nigeria. This study examined the effect of credit risk on financial performance and the rest of the study is structured in this manner: Section 2 considered the literature review from the perspective of conceptual, theoretical underpinning and empirical; In section 3, the methodology was undertaken; Section 4 considered the data analysis, results and discussion of findings and section 5, the study handled the summary, conclusion, recommendations and contribution to knowledge.

\section{Statement of the Problem}

Deposit money banks (DMBs) create loans from deposits from customers and these loans are major income generating source for majority of the banks. However this intermediation function of DMBs is associated with enormous risks to both the banks and the deficit units (Okorie \& Uwaleke, 2010). Banks are now working so hard to attract the massive number of people who are not banking with them. This has led to an increase in banks surplus units and deficit units as well. With the aim of increasing revenue and gaining a large portion of the market share, many banks have given out loans and advances which could not be recovered leading to a massive growth in Non-Performing Loans (NPLs) in their accounts. This has become a worrisome situation for banks and other stakeholders.

Moreover, empirical evidences on credit management and financial performance of deposit money banks reveal conflicting results. A study by (Uwalomwa, Uwuigbe \& Oyewo, 2015) on Credit Management and Bank Performance of Listed Banks in Nigeria revealed that ratio of nonperforming loans and bad debt do not have a significant negative effect on the performance of banks in Nigeria. While secured and unsecured loan ratio and bank's performance was not significant. A study by (Abu, Sajeda \& Mustafa, 2015) on the effect of credit risk on the banking profitability in Bangladesh finds a robust negative and significant effect of non-performing loan to gross loan, loan loss reserve to gross loan on all profitability indicators. The analysis also finds 
European Journal of Accounting, Auditing and Finance Research

Vol.8, No.2, pp.38-58, February 2020

Published by ECRTD-UK

Print ISSN: 2053-4086(Print), Online ISSN: 2053-4094(Online)

a negative and significant effect of capital adequacy ratio (CAR) on return on average equity. The implication is that the effect credit management has on a bank's financial performance cannot be undermined.Consequently, this study conducted a research to solve this identified problem

\section{Research Objectives}

The following objectives were set for this study:

i. To examine the effect of credit management on financial performance of money deposit banks in Nigeria;

ii. Investigate the effect of credit management with control variable of bank size on financial performance of money deposit banks in Nigeria.

Research Questions: The following research questions were answered in this study:

iii. What is the effect of credit management on financial performance of money deposit banks in Nigeria?

iv. What is the effect of credit management with control variable of bank size on financial performance of money deposit banks in Nigeria?

Research Hypotheses:The following hypotheses were tested in the study

i. Ho1: Credit management does not have any significant effect on financial

performance of money deposit banks in Nigeria.

ii. Ho2: Credit management with control variable of bank size does not have any significant effect on financial performance of money deposit banks in Nigeria

\section{REVIEW OF LITERATURE AND THEORETICAL FRAMEWORK}

\section{Conceptual Review}

Credit Risk of Deposit Money Banks: According to Chen and Pan (2012), it is the degree of value fluctuations in debt instruments and derivatives due to changes in the underlying credit quality of borrowers and counterparties. Banks are increasingly facing credit risk (or counterparty risk) in various financial instruments other than loans, including in the banking book, in the trading book, and both on and off the balance sheet thus acceptances, interbank transactions, trade financing, foreign exchange transactions, financial futures, swaps, bonds, equities, options, and in the extension of commitments and guarantees, and the settlement of transactions. Credit risk can be divided into three risks: default risk, exposure risk and recovery risk. Default can be defined as a missed or delayed payment of a contractual obligation or a bankruptcy filing or legal receivership of the obligor that will probably cause one or more missed or delayed future payment(s). Furthermore, default can be considered as a distressed exchange whereby the obligor offers creditors restructured debt, securities or assets that result in a diminished financial obligation relative to the original obligation. According to Komolafe (2017), credit risk also involves credit quality deterioration, which although is less severe than default will increase the future default probability.

Financial Performance of Deposit Money Bank: Credit risk management maximizes bank's risk adjusted Rate of return by maintaining credit risk exposure within acceptable limit in order to 
European Journal of Accounting, Auditing and Finance Research

Vol.8, No.2, pp.38-58, February 2020

Published by ECRTD-UK

Print ISSN: 2053-4086(Print), Online ISSN: 2053-4094(Online)

provide framework for understanding the effect of credit risk management on banks' profitability (Kargi, 2011). There are various yardsticks that can be used to measure the financial performance of a deposit money bank. Ideally, profitability and asset base are the two traditional measures of bank performance in Nigeria. While profitability pleases shareholders, asset base pleases the board of directors. In a similar note, Enendu, Abba, Fagge, Kure, Bewaji, Nwosu, Ben-Obi, Adigun, Elisha, Okoro and Ukeje (2013), posited Return on Assets (ROA) and Return on Capital Employed (ROCE) as the most popular standard metrics of bank performance traditionally. Return on assets is a standard measure of bank performance obtained by dividing profits by total assets. The numerator can be either before- or after tax profits. It gives management and shareholders a sense of how well the available resources are being employed. Return on assets (ROA) can expose low quality businesses but has a flaw of ignoring the effect of debt and taxation.

Theoretical Underpinning: The following theories were used in this study

The Credit Risk Theory: Credit risk refers to the risk of suffering a financial loss due to the decline in the creditworthiness of counterparty in a financial transaction (Liu, Mirzaei \& Vandoros, 2014). That the source of credit risk is the default risk that is the risk that a counterparty will not fulfill the contractual obligations. The risk is primarily that of the lender and includes lost principal and interest, disrupt loss may be complete or partial and can arise in a number of circumstances, such as an insolvent bank unable to return funds to a depositor.

Credit risk theory was introduced in 1974 by Robert Merton in his theory of default or default model which is the basic theory of credit risk. Robert proposed a model for assessing the credit risk of a company by characterizing the company's equity as a call option on its assets. There are two main methods of modeling credit risk which include the structural approach and the intensitybased approach (also known as reduced form approach). Leveraging on Merton model, three important approaches to measuring credit risk was derived by Clifford V. Rossi. These include; the concept of credit spreads, credit portfolio management and loss distribution generated through Monte Carlo simulation. To reduce the lenders risk, the lender may perform a credit check on the prospective borrower, may require the borrower to take appropriate insurance, such as mortgage insurance or seek security or guarantees of third parties. In general, the higher the risk, the higher will be the interest rate that the debtors will be asked to pay on the debt (Owojori, Akintoye \& Adidu, 2011).

\section{The Anticipated Income Theory}

The Anticipated Income Theory was developed by H.V. Prochnow in 1944 using the US commercial banks practice. According to this theory, regardless of the nature and character of a borrower's business, the bank should plan the liquidation of the term-loan (loan between one to five years) from the anticipated income of the borrower. This theory places emphasizes on the ability of the bank to advance loan base on the income that the borrower expects both in the shortterm and long-term. The bank tries to link their loan, both medium and long term, on the borrowers expected income. Thus a loan by the bank gets repaid out of the future income of the borrower in instalments, instead of in a lump sum at the maturity of the loan. The bank advances more loan when the expected incomes are regular and can be expected as at when due. This will in turn help 
European Journal of Accounting, Auditing and Finance Research

Vol.8, No.2, pp.38-58, February 2020

Published by ECRTD-UK

Print ISSN: 2053-4086(Print), Online ISSN: 2053-4094(Online)

the bank to manage its credit risk efficiently, since bank management can plan its credit base on expected income.

It is also generally known as "cash flow approach" to lending. This theory dominates the commercial loan theory and the shiftability theory as it satisfies the three major objectives of liquidity, safety and profitability. Properly understood, this theory was a rival only to the commercial loan theory. It focused attention on the types of loans appropriate for a bank to make but came to quite a different conclusion than that reached by the advocates of the commercial loan theory (Moti, Masinde \& Mugenda, 2012).

\section{Asymmetric Information Theory}

George Akerlof first argued about information asymmetry in a 1970 paper titled "The Market for Lemons". Michael Spence added to the debate with the 1973 paper "Job Market Signaling." Information Asymmetry reached mainstream acclaim with Joseph Stiglitz who has authored and co-authored several significant work on information asymmetry based on the theory of marked screening. Information asymmetry refers to a situation where business owners or manager know more about the prospects for, and risks facing their business, than do lenders (PWHC, 2002) cited in Eppy (2005). It describes a condition in which all parties involved in an undertaking do not know relevant information. In a debt market, information asymmetry arises when a borrower who takes a loan usually has better information about the potential risks and returns associated with investment projects for which the funds are earmarked. The lender on the other hand does not have sufficient information concerning the borrower (Edwards \& Turnbull, 1994).

Binks (1992) pointed out that perceived information asymmetry poses two problems for the banks, moral hazard (monitoring entrepreneurial behavior) and adverse selection (making errors in lending decisions). Banks will find it difficult to overcome these problems because it is not economical to devote resources to appraisal and monitoring where lending is for relatively small amounts. This is because data needed to screen credit applications and to monitor borrowers are not freely available to banks. Bankers face a situation of information asymmetry when assessing lending applications (Binks \& Ennew, 1996, 1997). The information required to assess the competence and commitment of the entrepreneur, and the prospects of the business is either not available, uneconomic to obtain or difficult to interpret. This creates two types of risks for the Banker (Deakins, 1999). The risk of adverse selection which occurs when banks lend to businesses which subsequently fail (type II error), or when they do not lend to businesses which go on to become" successful, or have the potential to do so (type I error) Altman (1971).

\section{Empirical Review}

Many prior studies had documented the nexus and effects credit risk and financial performance from the advanced, and the developing economies. Many of these studies have recorded divergence opinions and inconsistent results. Among them are the following studies: Oduro, Asiedu and Gadzo (2019) studied the effect of credit risk on corporate financial performance: evidence from listed banks on the Ghana stock exchange. The study identified the factors that determine the level of bank credit risk and also estimated the effects of bank credit risk on corporate financial performance from 2003 to 2017. Using the method of 2SLS, the study found 
European Journal of Accounting, Auditing and Finance Research

Vol.8, No.2, pp.38-58, February 2020

Published by ECRTD-UK

Print ISSN: 2053-4086(Print), Online ISSN: 2053-4094(Online)

that variables such as capital adequacy, operating efficiency, profitability, and net interest margin are inversely related to credit risk; while bank size and financing gap tend to relate positively with credit risk. Therefore, increase in bank credit risk negatively affects corporate financial performance in accordance with Basel accord. Thus, critical attention is paid to credit risk exposure by the management.

Kajola, Babatunji, Olabisi and Babatolu (2019) investigated the effect of credit management on financial performance of ten listed deposit money banks in Nigeria for the period, 2005 - 2016. Using Non-performing Loan to total Loan Ratio (NPLLR); Non-performing Loan to total Deposit Ratio (NPLDR) and Capital Adequacy Ratio as surrogate for credit management and Return on asset (ROA) and Return on equity (ROE) for financial performance, the study utilized random effects generalized least squares (GLS) regression as its data estimation technique. The study found that that all the three credit risk parameters have a significant relationship with ROA and ROE. The study recommended that the management of deposit money banks should develop rigorous and robust credit policies that would assist banks to effectively assess the creditworthiness of their customers. In addition, the regulatory agencies were advised to come up with modern credit risk measurements, identification and control; while prompt and necessary action should also be taken against the management of any bank that flouts their credit risk guidelines to prevent unpleasant distress in the financial system.

Collins, M-epbari, Sira and Grend (2018) examined the effect of credit management and bank performance in Nigeria. The study adopted cross sectional survey design. The population of the study consisted of all management staffs of commercial banks operating in Nigeria. The sample sizes of eleven (11) select commercial banks were considered by systematic technique. The Purposive sampling technique was adopted with six respondents administered questionnaire (Bank Manager and five senior staff) from each bank to make up a 66 respondents for the study. Multiple regression analysis was adopted for the study to determine the influence/effects of credit management variables (Credit Appraisal, Credit Risk Control, and Collection policy) on bank performance. The study revealed that credit management has a significant effect on bank performance in Nigeria. The study also revealed that among the credit management variables considered, credit risk control has the highest driving force for bring about an effect financial performance of bank in Nigeria. The study recommended that financial institution should not only take credit management serious, but should recognized the role of credit risk section if they aim at increasing profitability.

Olabamiji and Michael (2018) examined the influence of credit management practices on financial performance of Nigerian banks with specific reference to First bank Plc. Data was collected using Purposive sampling technique from thirty (30) respondents as a sample size used to collect data from the respondents. Both descriptive and inferential statistics were used to analyze data, such as frequency, percentage, weighted mean score, and multiple regression. The result revealed that credit management practices have a significant positive influence on the financial performance of First bank. The study concluded that client appraisal, credit risk control, and collection policy are major predictors of financial performance of First bank. Subsequently, the study recommended that management of other banks should learn from First bank by enhancing their client appraisal 
European Journal of Accounting, Auditing and Finance Research

Vol.8, No.2, pp.38-58, February 2020

Published by ECRTD-UK

Print ISSN: 2053-4086(Print), Online ISSN: 2053-4094(Online)

techniques, credit risk control and adopting a more stringent policy to improve their financial performance.

Aigbomian and Akinlosotu (2017) investigated credit risk management and profitability in deposit money banks in Ekpoma, Edo State-Nigeria. Descriptive research design was adopted covering all the nine (9) Deposit Money Banks in Ekpoma-Edo State. One hundred and fifty (150) bankers were drawn as sample from six deposit money banks in the area. The two instruments used in the study include: Banks' Credit risk Management Practices (BACRIMAP) for data on credit risk management practices and Profitability Satisfaction Inventory (PSI) to collect data on profitability indices of banks. Data were analyzed with percentages (\%), frequency distribution table, Mean and standard deviation while the hypotheses were tested with Bivariate Pearson Product Moment Correlation (PPMC) using Statistical Package for Social Sciences (IBM SPSSR). Results showed that: credit derivatives, credit Securitization, and adoption of a sound internal lending policy are the credit management strategies used in deposit money banks in Edo State. Findings further revealed that credit risk management has positive significant relationship with profitability of deposit money banks.

Taiwo, Ucheaga, Achugamonu, Adetiloye, Okoye and Agwu (2017) empirically investigate the quantitative effect of credit risk management on the performance of Nigeria's Deposit Money Banks (DMBs) and Bank lending growth over the period of 17 years (1998-2014). Secondary data for empirical analysis was obtained from CBN Statistical bulletin 2014 and World Bank (WDI) 2015. The study employed multiple linear regression model to analyze the time series data. The findings revealed that credit risk management has an insignificant effect on the growth of total loans and advances by Nigerian Deposit money banks. The result showed that sound credit management strategies can boost investors and savers confidence in banks and lead to a growth in funds for loans and advances which leads to increased bank profitability.

Nwanna and Oguezue (2017) examined the nexus between credit management and profitability (ROA) of Deposit Money Banks (DMBs) in Nigeria context for the period of 2006 to 2015. The study employed multiple regression technique in analyzing the data that gathered using ordinary least square. The study found that loans and advances and loan loss provision have positive and insignificant effect on profitability, while non-performing loan has a negative and insignificant effect on profitability. Thus, the study concluded that sound credit management heightens profitability and holds the financial strength of the DMBs. It was recommended that DMBs should put in place sound credit management policies and practice. Issue recoverable loan and advances and provide for loan losses for desired credit risk exposure and increased profitability.

Kolapo, Ayeni, Kolade and Oke (2012) empirically investigated the quantitative effect of credit risk on the performance of five commercial banks in Nigeria for the period2000 to 2010. Profit measured by Return on Asset (ROA), as a function of the ratio of Non-performing loan to loan \&Advances (NPL/LA), ratio of Total loan \& Advances to Total deposit (LA/TD) and the ratio of loan loss provision to classified loans (LLP/CL) as measures of credit risk. The results showed that the effect of credit risk on bank performance is cross-sectional invariant hence, similar across banks in Nigeria. A 100 percent increase in non-performing loan reduces profitability (ROA) by 
European Journal of Accounting, Auditing and Finance Research

Vol.8, No.2, pp.38-58, February 2020

Published by ECRTD-UK

Print ISSN: 2053-4086(Print), Online ISSN: 2053-4094(Online)

about 6.2percent while a 100 percent increase in loan loss provision also reduces profitability by about 0.65 percent and a100 percent increase in total loan and advances increase profitability by about 9.6 percent.

Bank size (Log of Total Assets) is generally used to capture potential economies or diseconomies of scale in the banking sector. This variable controls for cost differences in product and risk diversification according to the size of the financial institution. The first factor could lead to a positive relationship between size and bank profitability, if there are significant economies of scale (Akhavein et al. 1997; Bourke 1989; Molyneux and Thornton 1992; Bikker \& Hu 2002; Goddard, 2004), while the second to a negative one, if increased diversification leads to lower credit risk and thus lower returns. Other researchers however conclude that marginal cost savings can be achieved by increasing the size of the banking firm, especially as markets develop (Berger. 1987; Boyd and Runkle 1993; Miller and Noulas 1997; Athanasoglou, 2007). Eichengreen and Gibson (2001) suggest that the effect of a growing bank's size on profitability may be positive up to a certain limit. Beyond this point the effect of size could be negative due to bureaucratic and other reasons. Hence, the size-profitability relationship may be expected to be non-linear.Another part of the literature has been interested in the analysis of the theoretical arguments based on the relationship between the bank size and bank risk-taking. It suggests a negative relationship between these two variables. Such a relationship is justified by the most natural argument that is diversification by size. Indeed, larger banks are expected to have lower risks because they have the capability of holding more diversifiable portfolios. In this respect, many researches have been conducted. According to the researches of Saunders et al. (1990), Chen et al. (1998), Cebenoyan et al. (1999) and Megginson (2005), there is a negative relationship between bank risk and bank size. They explain this result by the fact that larger banks are likely to be more skilled in risk management and have also better diversification opportunities. Thus, we expect to find that the bank size is negatively related to the level of risk.

\section{Justification for the Study}

Credit management has always been one of the most important activities of financial institutions and cannot be overlooked or overemphasized. A suitable credit management policy is crucial in safeguarding the performance of the deposit money bank as it contributes enormously to the financial performance and determines how well their goals and objectives is achieved (Scheufler, 2002). If the credit approach is effectively figured, all around surmised at all levels of the banking related establishment and practiced, it enhances performance by diminishing non-performing loans and creating room for business improvement. There is paucity of literature on the topic of study in Nigeria as most studies are conducted outside Nigeria. The very few studies in Nigeria are either limited to few state: Edo state (Aigbomian \& Akinlosotu, 2017) and Lagos State (Alalade, Binuyo \& Oguntodu, 2014); or time limited (Taiwo, Ucheaga, Achugamonu, Adetiloye, Okoye \& Agwu, 2017:1998 - 2004), (Uwuigbe, Uwuigbe \& Oyewo, 2015:2007 - 2011), (Aruwa \& Musa, 2014: 1997 - 2011); Kolapo, Ayeni \& Oke, 2012: 2000 - 2010) and Onaolapo; 2012: 2004 - 2009). Raymond, Adigwe \& John-Akamelu (2015) focused the study to the manufacturing sector; without taking much cognizance to the entire economy. Other analyses done on the banking industry were not specific to the identified banks from the stress test as done in this study but are inclusive of all deposit money banks hence not problem specific. 
European Journal of Accounting, Auditing and Finance Research

Vol.8, No.2, pp.38-58, February 2020

Published by ECRTD-UK

Print ISSN: 2053-4086(Print), Online ISSN: 2053-4094(Online)

With the economic situation of the country whereby the banking market is facing serious headwinds from slow GDP growth, foreign exchange crisis to regulatory pressures; deposit money banks are recording huge non-performing loans from all the sectors of the economy especially the oil sector which use to be the most booming sector thereby exposing the industry greatly to the extent of surpassing the credit exposure limit threshold. The stress test conducted during this period buttress this as some banks were declared distressed and undercapitalized. This study will provide further analysis on the effect these banks as the acid test did not give insights on the effect of the misnomers on the financial performance of these banks. Additionally, no solution was recommended to manage the situation, the result of this analysis will guide in developing recommendations on how to curb the situation. Most of the gaps in the literature reviewed above are centered on methodological issues. Aigbomian and Akinlosotu (2017) used mean, standard deviation and correlation tools in studying credit risk management and profitability in deposit money banks in Ekpoma. These analytical tools as stated in Gujarati (2009) is not the best tool to study relationship between variables; as regression analysis adopted in the study is a better analytical. In addition, the study is limited to Ekpoma, Edo state which cannot be used to make generalizations for Nigeria. Moreover, using descriptive and inferential statistics to analyze the data in this study do not present a standard analytical tool for a study of this magnitude. This type of statistical tool for analysis was also adopted by Kibor, Ngahu and Kwasira (2015); Ezejiofor, Adigwe and John-Akamelu (2015); Alalade, Binuyo and Oguntodu (2014); and Babalola and Mohammed (2014). Muriithi, Waweru and Muturi (2016); and Oladere and Wan (2013) tried to use a more robust method of analysis but is not update. Also, Taiwo, Ucheaga, Achugamonu, Adetiloye, Okoye and Agwu (2017) empirically investigate the quantitative effect of credit risk management on the performance of Nigeria's Deposit Money Banks (DMBs) and Bank lending growth over the period of 17 years (1998- 2014). The study is not up to date and too short to have a robust time series analysis. The same is applicable to (Rauf 2016), using a short time period in the analysis is poor because it is difficult to separate the effect of credit risk management on the performance in the economy, all of which were taking place concurrently. The same is applicable to the study of Kagoyire and Shukla (2016); Uwuigbe, Uwuigbe, and Oyewo (2015); Kipkoech R.S. (2015); Talata (2015); Misker (2015); Ali (2015); Li and Zou (2014); Afriyie and Akotey (2013); Aruwa and Musa (2014); Al-Khouri (2011); Appah and John (2011); and Husni, (2011). A more recent analysis is germane following constant changes in the economic and financial environment across the globe. The study differs from previous studies by updating the time series data to 2017 and capturing Nigerian Banking Industry in its entirety. Most of these studies did not incorporate in their study periods current issues in the economy; unlike this study which captures specific and recent event in the banking industry by modelling the effect of poor credit management issues as reported by the Central Bank of Nigeria in certain distressed banks. It is therefore imperative that we control for the effects of other changes in the financial performance environment in the country. This approach has been largely ignored in the past empirical literature. Without adequately controlling for these other factors, the empirical results obtained may be biased. This study therefore contributes to the literature by incorporating other factors to provide empirical evidence on Nigeria for which previous studies have failed to incorporate. The study sought to address the gaps identified in literature with an updated, problem specific deposit money banks analysis. It provided a comprehensive analysis on the direction and nature of the relationship of credit management and financial performance. 
European Journal of Accounting, Auditing and Finance Research

Vol.8, No.2, pp.38-58, February 2020

Published by ECRTD-UK

Print ISSN: 2053-4086(Print), Online ISSN: 2053-4094(Online)

\section{METHODOLOGY}

This study adopted an expo facto research design. The population consisted of all the 19 money deposits banks (MDB) listed on the Nigeria stock exchange as at $31^{\text {st }}$ December, 2018. A sample of 13 MDB were chosen on purpose, based mainly on availability of complete data within the study period under consideration. The study covered 169 firm-year observations for the period of 2006-2018. The study extracted secondary data from the financial statements of the banks explored for the study. The study identified three variables of financial performance (dependent variable) surrogated with return on capital employed (ROCE), the independent variable of credit risk proxied with non-performing loans, capital adequacy ratio, loan loss provisions loan to deposit ratio and the control variables of bank Size.

\section{Measurement of Variables}

Return on capital Employed (ROCE): Capital employed equals a company's Equity plus Noncurrent liabilities or Total Assets minus Current Liabilities. In other words all the long-term funds used by the company. ROCE indicates the efficiency and profitability of a company's capital investments. Therefore, ROCE can be expressed as:

$\begin{array}{ll}\text { Net profit before interest and Tax } & 100 \\ \text { Total Assets - Cumulative Liabilities } & 1 .\end{array}$

Non-Performing Loans (NPL): The non-performing loans comprised the categories substandard (interest and/or principal are more than 90 days overdue), doubtful (interest and/or principal are overdue more than 180 days) and loss loans (where the loan is virtually uncollectible; interest and/or principal are overdue for more than a year), or the banks selected for the period ----Absolute figure.

Capital Adequacy Ratio (CAR): This study adopted capital adequacy ratio as total capital to risk adjusted assets of a bank

Loan Loss Provision (LLP): This study adopted the MDB' loan loss reserve ratio as the proxy for credit management for adequate measurement of banks managers' expectation of their asset quality.

Loans to Deposit Ratio (LDR): When the banks are more liquid, they can reduce risk of insolvency. The study just as the name implies, as a ratio of loans and advances to total deposit.

Model Specifications

$\mathrm{Y}_{\mathrm{it}}=\beta_{0}+\beta_{1} \mathrm{XZ}$ it $+\mu_{\mathrm{it}}$

Dependent Variable: $Y=y_{1}$

Independent Variable: $X=\mathrm{x}_{1}, \mathrm{x}_{2}, \mathrm{x}_{3}, \mathrm{x}_{4} ; \mathrm{Z}=\mathrm{z}_{1}$.

Control Variable: $\mathrm{Z}=\mathrm{z}_{1}$,

Where

$\mathrm{y}_{1}=$ Financial Performance (FP) 
$\mathrm{x}_{1}=$ Non-performing loan ratio (NPL)

$\mathrm{x}_{2}=$ Capital Adequacy ratio (CAR)

$\mathrm{x}_{3}=$ Loan Loss provision (LLP)

$\mathrm{X}_{4}=$ Loan to deposit ratio $(\mathrm{LDR})$

$\mathrm{Z}_{1}=\quad$ Bank Size $(\mathrm{BS})$

\section{Models}

$\mathrm{FP}=f(\mathrm{NPL}, \mathrm{CAR}, \mathrm{LLP}, \mathrm{LDR}) \quad$ Model 1

$\mathrm{FP}=f(\mathrm{NPL}, \mathrm{CAR}, \mathrm{LLP}, \mathrm{LDR}, \mathrm{BSZ}) \quad$ Model 2

$F P_{i t}=\beta_{0}+\beta_{1} N P L_{i t}+\beta_{2} C A R_{i t}+\beta_{3} L L P_{i t}+\beta_{4} L D R_{i t}+\mu_{i} \ldots \ldots \ldots \ldots \ldots \ldots \ldots \ldots \ldots$ main model A

$F P_{i t}=\beta_{0}+\beta_{1} N P L_{i t}+\beta_{2} C A R_{i t}+\beta_{3} L L P_{i t}+\beta_{4} L D R_{i t}+\beta_{5} B S Z_{i t}+\beta_{6} B T R_{i t}+\mu_{i} \ldots$ main model B

\section{ANALYSIS, RESULTS AND DISCUSSIONS}

\section{Diagnostics Tests}

\section{Descriptive Statistics}

Descriptive statistics of return on capital employed, dividend paid. Non-performing loan ratio, capital adequacy ratio, loan loss provision, loan to deposit ratio, bank size and total revenue of selected DMBs for the period of $2006-2018$ is presented in Table 4.1.1.

Table 4.1.1: The Descriptive Statistics

\begin{tabular}{|l|l|l|l|l|l|l|}
\hline & $\begin{array}{l}\text { ROC } \\
\text { E }\end{array}$ & NPL & CAR & LLP & $\begin{array}{l}\text { LT } \\
\text { D }\end{array}$ & BSZ \\
\hline Mean & 1.29 & 11.37 & 12.71 & -3.55 & $\begin{array}{l}61.3 \\
4\end{array}$ & 8.95 \\
\hline Std.Dev. & 2.81 & 23.3 & 16.94 & 7.56 & $\begin{array}{l}18.8 \\
6\end{array}$ & 0.44 \\
\hline Min. & - & 0 & $\begin{array}{l}- \\
154.7\end{array}$ & -56.9 & 4 & 8.03 \\
& 20.23 & & 5 & & & \\
\hline Max. & 9.54 & 235.36 & 30.98 & 50.28 & 106 & 10.77 \\
\hline Obs & 169 & 169 & 169 & 169 & 169 & 169 \\
\hline
\end{tabular}

Source: Author's Work (2019)

As presented in Table 4.1.1, on the average, the return on every naira of capital employed is 1.29 , while the least is -20.23 and the most is 9.54. -20.23 is an indication of periods of losses; that is the banks reported losses at some periods within the time frame of this study. 
European Journal of Accounting, Auditing and Finance Research

Vol.8, No.2, pp.38-58, February 2020

Published by ECRTD-UK

Print ISSN: 2053-4086(Print), Online ISSN: 2053-4094(Online)

Multicolinearity Test: The multicolinearity test was conducted using Variance Inflation Factor VIF).

Table 4.1.2: Variance Inflation Factor Test

\begin{tabular}{|l|l|l|}
\hline Variable & VIF & 1/VIF \\
\hline LLP & 1.05 & 0.954148 \\
\hline CAR & 1.19 & 0.840549 \\
\hline NPL & 1.23 & 0.810082 \\
\hline LTD & 1.24 & 0.804589 \\
\hline BSZ & 4.73 & 0.211341 \\
\hline Mean VIF & 1.888 & \\
\hline
\end{tabular}

Source: Author's Work (2019)

In Baltagi (2015), the benchmark for Mean of the Variance Inflation Factor is 5.0 while for the individual reverse factor is 1 and the average is 1.888. This indicated no multicolinearity problems and that the series are suitable for the analysis.

Regression Results

Effect of Credit Risk on Financial Performance without Control Variable

Table 4. Credit Risk and Financial Performance without Control Variable

\begin{tabular}{|c|c|c|c|c|}
\hline \multirow[b]{3}{*}{ Variable } & \multicolumn{4}{|l|}{ ROCE } \\
\hline & \multicolumn{4}{|c|}{ RE GLS (DRISCOLL-KRAAY STD. ERR. } \\
\hline & Coeff & Std.Err & t-test & Prob \\
\hline NPL & -0.013 & 0.002 & -5.24 & 0.00 \\
\hline CAR & 0.059 & 0.004 & 12.22 & 0.00 \\
\hline LLP & 0.175 & 0.037 & 4.78 & 0.00 \\
\hline LTD & 0.009 & 0.003 & 2.65 & 0.02 \\
\hline Constant & 1.863 & 0.241 & 7.72 & 0.00 \\
\hline Adj. R ${ }^{2}$; F-Stat (Prob) & \multicolumn{4}{|c|}{$0.4196 ;$ Wald chi $^{2}(4)=241.2(0.00)$} \\
\hline Hausman Test & \multicolumn{4}{|c|}{$\mathrm{chi}^{2}(4)=9.07(0.06)$} \\
\hline Breusch Pagan LM Test & \multicolumn{4}{|c|}{$\operatorname{chi}_{(1)}^{2}=6.63(0.01)$} \\
\hline Heteroskedasticity Test & \multicolumn{4}{|c|}{$\operatorname{chi}^{2}(1)=315.10(0.00)$} \\
\hline Pesaran CD Test & \multicolumn{4}{|c|}{$8.812(0.00)$} \\
\hline $\begin{array}{ll}\text { Serial } & \text { Auto-Correlation } \\
\end{array}$ & \multicolumn{4}{|c|}{$F_{(1,12)}=4.584(0.054)$} \\
\hline
\end{tabular}

Source: Author's Work (2019)

Without Control Variables)

$\mathrm{FP}_{\mathrm{it}}=\beta_{0}+\beta_{1} \mathrm{NPL}_{\mathrm{it}}+\beta_{2} \mathrm{CAR}_{\mathrm{it}}+\beta_{3} \mathrm{LLP}_{\mathrm{it}}+\beta_{4} \mathrm{LTD}_{\mathrm{it}}+\mu_{\mathrm{i}}$

$\mathrm{ROCE}_{\mathrm{it}}=1.863-0.013 \mathrm{NPL}_{\mathrm{it}}+0.059 \mathrm{CAR}_{\mathrm{it}}+0.175 \mathrm{LLP}_{\mathrm{it}}+0.009 \mathrm{LTD}_{\mathrm{it}}$

\section{Interpretation}

Diagnostic Tests

The results of the Hausman tests for both models determining the most appropriate estimating technique between Fixed Effect and Random Effect conducted at significance level of 5 per cent; with $\rho$-values of 0.06 being higher than the 5 per cent level of significance chosen for the study reveal that Random Effect is the most appropriate estimator according to its null hypothesis which 
European Journal of Accounting, Auditing and Finance Research

Vol.8, No.2, pp.38-58, February 2020

Published by ECRTD-UK

Print ISSN: 2053-4086(Print), Online ISSN: 2053-4094(Online)

states that there is presence of unsystematic difference in the model coefficients; thus, the study does accept the null hypothesis. The confirmatory tests on the results of Hausman tests conducted using Breusch-Pagan Lagrangian Multiplier test, deciding the most appropriate estimating technique between the random effects and pooled OLS, with null form of "no panel effect" that is "no significant difference across units". The results with $\rho$-values of 0.01 confirmed the appropriateness of the random Effect that there exist a panel effect for the Model

Cross-sectional Independence Test is only applicable when there exist a panel effect the result with $\rho$-values of 0.00 revealed that the residuals of the model across the firms " $i$ " are correlated over time " $t$ ". Breusch-Pagan/Cook-Weisberg Test with $\rho$-values of 0.00 indicated that there is presence of heteroskedasticity problem in both models; which implies that the variations in the residuals of the model over the period " $t$ " in both models are trending. The existence of associations among the coefficients of the model and its residuals were tested using Wooldridge test for serial autocorrelation as an unhealthy association result to the error terms being smaller than expected and the co-efficient of determination being higher than normal. The statistics derived with $\rho$-values of 0.053 support the null hypothesis which states that there is no first order autocorrelation for Model. Based on the results of the diagnostic tests carried out; the Model is estimated using Random Effect Generalized Least Square with Driscoll-Kraay Standard Errors.

$\mathrm{FP}_{\mathrm{it}}=\beta_{0}+\beta_{1} \mathrm{NPL}_{\mathrm{it}}+\beta_{2} \mathrm{CAR}_{\mathrm{it}}+\beta_{3} \mathrm{LLP}_{\mathrm{it}}+\beta_{4} \mathrm{LTD}_{\mathrm{it}}+\mu_{\mathrm{i}}$

$\mathrm{ROCE}_{\mathrm{it}}=1.863-0.013 \mathrm{NPL}_{\mathrm{it}}+0.059 \mathrm{CAR}_{\mathrm{it}}+0.175 \mathrm{LLP}_{\mathrm{it}}+0.009 \mathrm{LTD}_{\mathrm{it}}$

The multiple linear regression estimate of Model 5 shows that non-performing loans ratio has significant negative effect on financial performance measured by return on capital employed (ROCE) $(\beta=-0.013, p(0.00)<0.05)$ capital adequacy ratio, has significant positive effect on financial performance measured by return on capital employed (ROCE) $(\beta=0.059 ; 0.175 ; 0.009$, $p(0.00 ; 0.00 ; 0.02)<0.05)$ but insignificant positive effect on financial performance, which are consistent with the a priori expectation that non-performing loans ratio has a negative effect on Financial Performance while capital adequacy ratio, loan loss Provision ratio, and loan to total deposit ratio have positive effect on financial performance of Deposit Money Banks in Nigeria. Based on the size and sign of the independent variable coefficients; a $1 \%$ increase in NPL should on average result to $0.013 \%$ in return on capital employed and dividend per share respectively; $1 \%$ increase in capital adequacy ratio should on average result to $0.059 \%$ increase in return on capital employed and dividend per share respectively; $1 \%$ increase in loan loss provision ratio should on average result to $0.175 \%$ increase in return on capital employed and dividend per share respectively; and $1 \%$ increase in loan to total deposit ratio should on average result to $0.009 \%$ increase in return on capital employed and dividend per share respectively.

Furthermore, the Adjusted R-squared shows 0.4196 on ROCE. This shows that about $41.96 \%$ variations in ROCE can be attributed to credit management surrogates (non-performing loan ratio, capital adequacy ratio, loan loss Provision ratio, and loan to total deposit ratio) hence 50.04\% variation in ROCE are attributed to other factors not included in the model.. From the result of the F-statistics, with p-values of 0.00 , it is deduced that credit management significantly affects financial performance (ROCE) of listed Deposit Money Banks in Nigeria. Conclusively, using 
European Journal of Accounting, Auditing and Finance Research

Vol.8, No.2, pp.38-58, February 2020

Published by ECRTD-UK

Print ISSN: 2053-4086(Print), Online ISSN: 2053-4094(Online)

ROCE as measures of financial performance, this study failed to accept the null hypothesis which states that "credit management has no significant effect on financial performance of Deposit Money Banks in Nigeria

Effect of Credit Risk on Financial Performance with Control Variable of Bank Size Table 4.2.6: Credit Risk and Financial Performance with Control variables

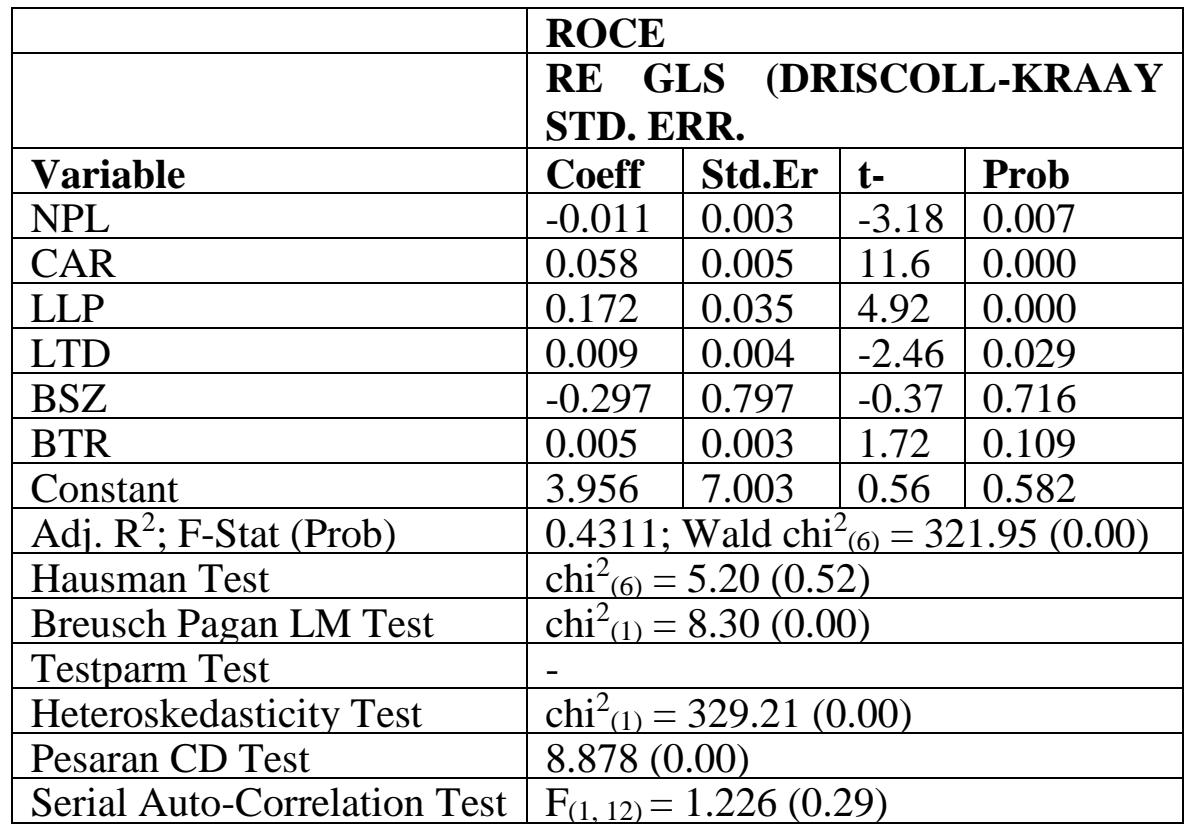

Source: Author's Work (2019)

With Control Variable

$\mathrm{FP}_{i \mathrm{t}}=\beta_{0}+\beta_{1} \mathrm{NPL}_{\mathrm{it}}+\beta_{2} \mathrm{CAR}_{\mathrm{it}}+\beta_{3} \mathrm{LLP}_{\mathrm{it}}+\beta_{4} \mathrm{LDR}_{\mathrm{it}}+\beta_{5} \mathrm{BSZ}_{\mathrm{it}}+\mu_{\mathrm{i}}$

$\mathrm{ROCE}_{\mathrm{it}}=3.956-0.011 \mathrm{NPL}_{\mathrm{it}}+0.058 \mathrm{CAR}_{\mathrm{it}}+0.172 \mathrm{LLP}_{\mathrm{it}}+0.009 \mathrm{LTD}_{\mathrm{it}}-0.297 \mathrm{BSZ}_{\mathrm{it}}$

\section{Interpretation}

\section{Diagnostic Tests}

The results of the Hausman tests for both models determining the most appropriate estimating technique between Fixed Effect and Random Effect conducted at significance level of 5 per cent; with $\rho$-values of $0.52>0.05$, and $0.00<0.05$ reveal that while Random Effect is the most appropriate estimator for the Model. The confirmatory tests on the results of Hausman tests conducted using Breusch-Pagan Lagrangian Multiplier test, deciding the most appropriate estimating technique between the random effects and pooled OLS for the Model, with null form of "no panel effect" that is "no significant difference across units". The results with $\rho$-values of 0.00 confirmed the appropriateness of the random Effect that there exist a panel effect for the Model (ROCE).

Cross-sectional Independence Test for both Models with $\rho$-values of 0.00 and 0.01 revealed that the residuals of the model across the firms "i" are correlated over time " $t$ ". Breusch-Pagan/CookWeisberg Test and Modified Wald Test with $\rho$-values of 0.00 and 0.00 indicated that there is 
European Journal of Accounting, Auditing and Finance Research

Vol.8, No.2, pp.38-58, February 2020

Published by ECRTD-UK

Print ISSN: 2053-4086(Print), Online ISSN: 2053-4094(Online)

presence of heteroskedasticity problem in both models; which implies that the variations in the residuals of the model over the period " $t$ " in both Models are unstable over time. The existence of associations among the coefficients of the model and its residuals were tested using Wooldridge test for serial auto-correlation as an unhealthy association result to the error terms being smaller than expected and the co-efficient of determination being higher than normal. The statistics derived with $\rho$-values of 0.29 support the null hypothesis which states that there is no first order autocorrelation for both models. This implies that there is no unhealthy association among the coefficients of the models and its residuals in both models. Based on the results of the diagnostic tests carried out; The Model is estimated using Random Effect Generalized Least Square with Driscoll-Kraay Standard Errors

$\mathrm{FP}_{\mathrm{it}}=\beta_{0}+\beta_{1} \mathrm{NPL}_{\mathrm{it}}+\beta_{2} \mathrm{CAR}_{\mathrm{it}}+\beta_{3} \mathrm{LLP}_{\mathrm{it}}+\beta_{4} \mathrm{LDR}_{\mathrm{it}}+\beta_{5} \mathrm{BSZ}_{\mathrm{it}}+\beta_{6} \mathrm{BTR}_{\mathrm{it}}+\mu_{\mathrm{i}}$

$\mathrm{ROCE}_{\mathrm{it}}=3.956-0.011 \mathrm{NPL}_{\mathrm{it}}+0.058 \mathrm{CAR}_{\mathrm{it}}+0.172 \mathrm{LLP}_{\mathrm{it}}+0.009 \mathrm{LTD}_{\mathrm{it}}-0.297 \mathrm{BSZ}_{\mathrm{it}}+0.005 \mathrm{BTR}_{\mathrm{it}}$

$\mathrm{DPRS}_{\mathrm{it}}=-4.272-0.001 \mathrm{NPL}_{\mathrm{it}}+0.002 \mathrm{CAR}_{\mathrm{it}}+0.008 \mathrm{LLP}_{\mathrm{it}}+0.003 \mathrm{LTD}_{\mathrm{it}}+0.479 \mathrm{BSZ}_{\mathrm{it}}+0.002 \mathrm{BTR}_{\mathrm{it}}$

The multiple linear regression estimate of Model 6 shows that non-performing loans ratio has significant negative effect on financial performance measured by return on capital employed (ROCE) but insignificant negative effect on Dividend per Share (DPRS) $(\beta=-0.011, p(0.01)<$ 0.05 capital adequacy ratio, has significant positive effect on financial performance measured by return on capital employed (ROCE) $(\beta=0.058 ; 0.009, p(0.00 ; 0.03)<0.05)$ while loan loss Provision ratio has significant positive effect on both the ROCE $((\beta=0.172, p(0.00)<0.05)$ which are consistent with the a priori expectation that non-performing loans ratio has a negative effect on Financial Performance while capital adequacy ratio, loan loss Provision ratio, and loan to total deposit ratio have positive effect on financial performance of Deposit Money Banks in Nigeria. Also, Bank size has insignificant negative effect on ROCE $(\beta=-0.297, p(0.716)>0.05$ while Bank total revenue has insignificant positive effect positive effect on financial performance $(\beta=$ $0.005, p(0.109)>0.05$

Based on the size and sign of the independent variable coefficients; a 1\% increase in NPL should on average result to $0.011 \%$ in return on capital employed and dividend per share respectively; $1 \%$ increase in capital adequacy ratio should on average result to $0.058 \%$ and dividend per share respectively; $1 \%$ increase in loan loss provision ratio should on average result to $0.172 \%$ in return on capital employed and dividend per share respectively; $1 \%$ increase in loan to total deposit ratio should on average result to $0.009 \%$ on capital employed and dividend per share respectively; $1 \%$ increase in bank size should on average result to $0.297 \%$ decrease in return on capital employed while 1 million naira increase in bank total revenue should on average result to $0.005 \%$ on capital employed and dividend per share respectively.

Furthermore, the Adjusted R-squared shows 0.4311 on ROCE model. This shows that about $43.11 \%$ variations in ROCE can be attributed to credit management surrogates (non-performing loan ratio, capital adequacy ratio, loan loss Provision ratio, and loan to total deposit ratio) hence $56.89 \%$ variation in ROCE are attributed to other factors not included in the model. From the result of the F-statistics, with $p$-values of 0.00 , it is deduced that credit management significantly affects 
European Journal of Accounting, Auditing and Finance Research

Vol.8, No.2, pp.38-58, February 2020

Published by ECRTD-UK

Print ISSN: 2053-4086(Print), Online ISSN: 2053-4094(Online)

financial performance of listed Deposit Money Banks in Nigeria using both ROCE as measures of financial performance.

\section{DISCUSSION OF FINDINGS}

The findings of the analysis aligns with the result of the previous studies on the subject matter such as Hosna, Manzura and Juanjuan (2017) revealed that non-performing loans indicator has effect on profitability as measured by (ROE) more than capital adequacy ratio. In the same vein, Ozurumba (2016) examined the effect of non-performing loans, provision for loan loss and loans and advances on the performance of banks measured by Return on Assets and Return on Equity. The finding reveals that return on asset and return on equity have inverse relationship with nonperforming loans and loan loss provision respectively. Muriithi, Waweru and Muturi (2016) who studied the effect of credit risk on financial performance of commercial banks in Kenya found that credit risk has a negative and significant relationship with bank profitability. In addition, Nwanna and Oguezue (2017) in their study of the nexus between credit management and profitability (ROA) of Deposit Money Banks (DMBs) in Nigeria for the period of 2006 to 2015 showed that that loans and advances and loan loss provision have positive and insignificant effect on profitability; while non-performing loan has a negative and insignificant effect on profitability.

Implications of the Findings: The findings of the study have implications for the banks managers, regulators and the public. High co-efficient of determination implies that financial performance of deposit money banks is greatly influenced by the management of credit risk of deposit money banks. This further stresses the importance of adequate credit risk management for a healthy deposit money bank. The regulators will use the findings of this study useful to formulate a good policy that will safeguard the various investments of the bank and the varours stakeholders.Furthermore, attention should be paid to non-performing loans and loan to deposit ratio which consistently revealed negative effect on financial performance in the two models. The implication of the research findings is that a conscious drive targeted towards reducing the nonperforming loan ratio will improve the credit management as well as the performance.

Hence, a drive by the regulators to reduce and maintain healthy non-performing loans and loan to deposit ratio of DMBs will significantly improve performance of the financial system as well as promote financial and economic development.

\section{CONCLUSION, RECOMMENDATIONS AND CONTRIBUTION TO KNOWLEDGE}

\section{Conclusion}

The study examined the effect of credit management on the financial performance of deposit money banks in Nigeria for 2006 to 2018. Paucity of literature exists on the subject matter with respect to the proxy variables utilized in the study. The dependent variable, financial performance, was measured by return on capital employed and dividend paid per share while credit management was measured by non-performing loans ratio, capital adequacy ratio, loan to deposit ratio, loan loss provision as total revenue and bank size serve as control variables.Credit management decision is one of the most significant decisions taken by deposit money banks to maximize their financial performance and achieve a sustainable growth. In accordance with the object of this study 
European Journal of Accounting, Auditing and Finance Research

Vol.8, No.2, pp.38-58, February 2020

Published by ECRTD-UK

Print ISSN: 2053-4086(Print), Online ISSN: 2053-4094(Online)

and from the findings of the regression analysis which reveal that non-performing loan, capital adequacy ratio and loan to deposit ratio have negative significant relationship with return on capital employed while loan loss provision has a positive significant effect on return on capital employed; and also that non-performing loan and loan to deposit ratio have a negative significant effect on dividend per share while capital adequacy ratio and loan loss provision have positive significant effect on dividend per share; we therefore conclude that credit management is one of the major determinants of financial performance of a deposit money bank with significant effect on their financial performance. Hence, poor credit management framework cost the financial system while good credit management framework improves the financial performance of Deposit Money Banks.

\section{Recommendations}

In line with the findings of this study, the study recommended that, the management of the deposit money banks in Nigeria should design and maintain a robust credit management strategy \& framework as well as stringent credit policy that would decrease non-performing loan and default level; and improve their performance level. In addition, irrespective the size of the banks, the managers should not underplay the importance of capital adequacy, hence consistent evaluation of the capital adequate ratio is paramount.

Furthermore, the management of Nigerian DMBs should also match their loan assets to the nature of their deposit liabilities. Hence savings deposit should be used for short term investment or loan while time (fixed) term deposit is matched with long-term bonds while careful and detailed appraisal process should be followed in extending loans and advances to customers; and credit to individuals should be short-term or medium term at most.

Given that non-performing loan ratio has the highest effect on financial performance among other independent variables in the regression models, it is apparent that DMBs should pay greater attention to their non-performing loan ratio and formulate means and strategies to drive down the NPL ratio and maintain it at the barest minimum possible.

\section{Contribution to Knowledge}

This study has contributed to the literature by filling gap in the previous research of testing the effect of credit management on the financial performance of deposit money banks in Nigerian concentrating majorly on reported distressed banks in the financial system. This has helped us to ascertain how poor credit management which resulted to distress in the selected banks affect their financial performance.

The study establishes the significance of the relationship between credit management and financial performance in Nigerian Deposit Money Banks. In addition, the study deviated from existing literature by including return on capital employed and dividend per share as proxy variables for financial performance; so as to determine the effect from a different dimension.

Furthermore, this study has also updated research of this nature and assisted in proffering solutions to credit management issues in Nigeria. Hence, the study provide bank managers, financial analysts, investors and regulators further knowledge and valuable information that could be 
European Journal of Accounting, Auditing and Finance Research

Vol.8, No.2, pp.38-58, February 2020

Published by ECRTD-UK

Print ISSN: 2053-4086(Print), Online ISSN: 2053-4094(Online)

utilized as they make relevant financial decisions. It inform banks management of their efficiency level in loan administration as well as the magnitude of efficiency required to surpass minimum standard or achieve a given target.

\section{REFERENCES}

Abu, H. N., Sajeda, P., Mustafa, M. C., \& Hasanul, B. (2015). The Effect of Credit Risk on the Banking Profitability: A Case on Bangladesh. Global Journal of Management and Business Research: C Finance, 15(3), 41-48.

Aigbomian, E., \& Akinlosotu, B. (2017). Credit risk management and profitability of deposit money banks in Ekpoma, Edo State. Journal of Economics and Sustainable Development, $8(3), 222-235$.

Chen, K., \& Pan, C. (2012). An empirical study of credit risk efficiency of banking industry in Taiwan. Web Journal of Chinese Management Review, 15(1), 1-16.

Collins, A., M-epbari, O.N., Sira, Z., \& Grend, M. (2018). Effect of Credit Management on Bank Performance in Nigeria. Equatorial Journal of Finance and Management Sciences, 3(1), $17-23$.

Balgati, B. H. (2015). Econometrics manual: Applying the maxima open-source computer algebra system, (2nd Ed.) Springer Science Business Media, New York

Enendu, C. I., Abba, M. A., Fagge, A. I., Nakorji, M., Kure, E. U., Bewaji, P. N. (2013). Bank Intermediation in Nigeria: Growth, competition, and performance of the banking industry, 1990 2010. Central Bank of Nigeria Occasional Working Paper, (48).

Hashem, F. N. R., Alduneibat, K. A. A., \& Altawalbeh, A, F. (2017). The impacts of nonperforming loans upon the prices of stocks in Jordanian commercial banks Account. Finance Research. 6(1), 132-139.

Hosna, A., Manzura, B., \& Juan-juan, S. (2009). Credit risk management and profitability in commercial banks in Sweden. Semantic Scholars, 1(1), 234-245.

Kajola, S. O., Babatunji, A., Olabisi, J., Babatolu, A. T. (2019). Effect of credit riskmanagement on financial performance of Nigerian listed deposit money banks. Scholedge International Journal of Business Policy \& Governance, 5(6), 53-62.

Kargi, H. S. (2011). Credit Risk and the Performance of Nigerian Banks. Zaria: Ahmadu Bello University Press.

Komolafe, B. (2017, November), Senate to increase AMCON powers for speedy loan recovery. (retrieved from https://www.vanguardngr.com/2017/11/senate-increase-amcon-powersspeedy-loan-' recovery/ . Retrieved: 19/01/2019.

Liu, G., Mirzaei, A., \& Vandoros, S. (2014). The impact of bank competition and concentration on industrial growth. Economics Letters, 124(1), 60-63.

Mehmood, R., Hunjra, A. I., \& Chani, M. I. (2019). The impact of corporate diversification and financial structure on firm performance: Evidence from South Asian countries. Journal of Risk and Financial Management, 1-17.

Muriithi, J. G., Waweru, K. M., \& Muturi, M. M. (2017). Effect of credit risk on financial performance of commercial banks Kenya. IOSR Journal of Economics and Finance, 7(4), 72-83. 
Nwanna, I. O., \& Oguezue, F. C. (2017). Effect of credit management on profitability of deposit money banks in Nigeria. International Institute of Academic Research and Development, $3(2), 137-160$

Oduro, R., Asiedu, M. A., \& Gadzo, S. G. (2019). Effect of credit risk on corporate financial performance: Evidence from listed banks on the Ghana stock exchange. Journal of Economics and International Finance, 11(1), 1-14.

Okorie, G., \& Uwaleke, U. J. (2010). An overview of financial sector reforms and intermediation in Nigeria. Central Bank of Nigeria Bullion, 34(2), $19-29$.

Olabamiji, O., \& Michael, O. (2018). Credit management practices and bank performance: Evidence from First bank. South Asian Journal of Social Studies and Economics, 1(1), 110

Owojori, A. A., Akintoye, I. R., \& Adidu, F. A. (2011). The challenge of risk management in Nigerian banks in the post consolidation era. Journal of Accounting and Taxation. 3(2), 21-23.

Taiwo, J. N., Ucheaga, E. G., Achugamonu, B. U., Adetiloye, K. A., Okoye, L. U. \& Agwu,M. E. (2017). Credit Risk Management: Implications on Bank Performance and Lending Growth. Saudi Journal of Business and Management Studies, 2(5B), 584- 590.

Uwalomwa, U., Uwuigbe, O. R., \& Oyewo, B. (2015). Credit management and bank performance of listed banks in Nigeria. Journal of Economics and Sustainable Development, $\quad 6(2)$, 27-32. 